\title{
TENDENCY OF USING CHEMICAL, BIOLOGICAL, RADIOLOGICAL AND NUCLEAR WEAPONS FOR TERRORIST PURPOSES
}

\author{
Marko M. Krstić \\ Ministry of Internal Affairs of the Republic of Serbia, \\ Police Department in Šabac, Šabac, Republic of Serbia, \\ e-mail: marko.krstic.1982@gmail.com, \\ ORCID iD: (Dhttp://orcid.org/0000-0003-1947-4794
}

https://dx.doi.org/10.5937/vojtehg65-11223

FIELD: CBRN weapons and protection

ARTICLE TYPE: Review Paper

ARTICLE LANGUAGE: English

\section{Summary:}

Chemical, biological, radiological and nuclear (CBRN) terrorism is a serious problem, and its threat and use lead to a new era of terrorism: the epoch much more dangerous than any of the previous periods and the terrorism no one yet knows how to cope with. The disturbing fact is that terrorists can come into possession of weapons of mass destruction. Therefore, the goal of the paper is to analyze the probability of CBRN terrorist actions which have highlighted the growing concerns and increasing signs of convergence between terrorism and CBRN unconventional weapons for terrorist purposes. Terrorism today includes technologies available to anyone and anywhere and deployed through innovative solutions where it is also necessary to understand a complex interaction between the dynamic behavior of terrorist groups and the decisions regarding old and new technologies. The prospect of the use of CBRN terrorism has been confirmed by many countries as an acute security challenge that requires an efficient and quick response and reaction. The paper will also explain the importance of understanding the relationship between terrorist groups and non-conventional weapons, as well as difficulties in identifying factors that may cause the escalation. Since the end of 1990s and since the tragedy of September 11, 2001 in particular, government officials of many countries have pointed out the possibility that terrorist organizations eventually can come into the possession of unconventional materials and develop the possibilities of their use against some countries.

Key words: terrorism, CBRN weapon, unconventional weapons, new technologies, security challenge. 


\section{Introduction}

Terrorism is a complex social phenomenon, because its causes, nature and objectives as well as the identity of perpetrators vary by epochs or societies. Generally, terrorism is an anti-legal activity that uses or threatens to use violence to instill chronic fear in victims in search of the strategic objectives of terrorists. Terrorist acts are intended to create disorder and insecurity in which reality is perceived as temporary and unstable, especially when the issues of mortality are raised. The use of CBRN weapons for the purpose of warfare has been present for centuries; the use of these weapons for the purposes of terrorism is also very old, but there are significant differences between conventional wars and terrorism. In these circumstances, the biggest challenges for a community are likely to occur if a terrorist act involves the use of CBRN weapons.

Types of terrorism vary depending on the motivation, function, effects, nature of violence and strategies. Terrorists have always been connected, on an amateur basis initially and today they can intend more or less to commit mass attacks with greater number of casualties than it was the case 20 years ago, for example.

The studies of a few cases of earlier CBRN actions have led experts to identify the key characteristics of terrorist groups that could potentially have an interest to use these weapons. It is thought that conservatism is inherent in terrorist organizations, but it must not be forgotten that some terrorists are inclined to innovations in weapons and tactics, as well as to taking risks in actions or in the choice of weapons. Many experts agree that most terrorist organizations want to use proven methods to achieve desired effects. Innovations, especially in the field of CBRN weapons, often indicate terrorists are likely to be led by other factors rather than by pure curiosity and desire to experiment. For some individuals, repression and democratic and strong rule of law are positive determinants of the emergence of CBRN actions which points to a new and more complex global security environment with an increasing risk of terrorists trying to perform a CBRN attack. It is a frightening fact that a single terrorist or isolated terrorist group could improvise a biological weapon or use other ways to spread anthrax, smallpox or other biological agents and thereby cause mass casualties and destroy the health care system of a state.

CBRN weapons are secretly shipped to terrorists or hostile governments and represent a significant and growing threat to many countries. Although the threat of CBRN attacks is widely recognized as the central issue of national security, most analysts assume that the primary danger is a threat of the military use of these weapons in conventional wars with tra- 
ditional military means while the threat of covert attacks, which include terrorism, is rashly and unfairly neglected. Covert attacks are difficult to deter or prevent and CBRN weapons suitable for this type of attack are available to a growing number of enemy states and groups. At the same time, restrictions on their use appear to be diminishing, and so-called new terrorists do not always escalate and become apparent only by using unconventional weapons. These weapons are easily spread or transmitted from person to person, have a high mortality rate and a potential impact on public health, causing mass casualties that can crush health systems and cause public panic and social disruption, thus requiring special efforts to suppress them.

When assessing the threat of CBRN weapons, we should take into account the change in capacity to carry out terrorist attacks that are on the rise among countries and non-government elements. Analysts believe that the fear of chemical and biological terrorist attacks is excessive, they point out that, in the past, very few attacks involved these weapons, and even those few attempts that have occurred were mostly thwarted by the authorities. A relative ease with which biological weapons can be obtained, along with other current changes and turbulences in the world, sets the stage for another type of warfare in the 21st century.

The potential for CBRN terrorism has widely grown since 11 September, when some of these materials were used. The danger of terrorist use of nuclear weapons and other weapons of mass destruction represents a very serious threat for many countries; if a terrorist group could gain access to this weapon, it is highly likely it would use it, or threaten to use it. Although there is very little information on terrorists and their ability to come into possession of nuclear weapons or on their intentions to get them, the risk of CBRN weapons has certainly increased since the terrorists started to become more familiar with these agents and their harmful consequences.

Discovering the nature of the threat of biological weapons, as well as the appropriate response to them requires an emphasis on the biological characteristics of these instruments of war and terror. Preparing for a terrorist attack may seem daunting and there are a small number of people with practical experience and a good knowledge of CBRN weapons, because until recently there was no need to own them. In the past, most of the planning regarding emergency response to terrorism concentrated on the concerns of open attacks (bombing). However, the threats of CBRN weapons are taken seriously, especially in the USA, where media, fascinated by new weapons of mass destruction, encourage a growing fear for public safety. Terrorists who have significant human and material resources are much more likely to realize their intentions than lone perpetrators or small 
terrorist groups. A CBRN terrorism threat is certainly a matter of concern; however, terrorists will face many obstacles in the implementation of an attack of this kind. This includes the acquisition of materials and preparation for spreading them as well as a selection and a survey of a chosen objective and a correct dose required to achieve a desired effect.

\section{The growing threat of CBRN terrorism}

Terrorism can be defined as a deliberate act of violence intended to cause damage, but also to create an appropriate political and ideological situation, so that the use of these non-traditional weapons of terror outside the context is obvious, and the goals will not be military, but civilian ones (Bioterrorism, chemical weapons, and radiation terrorism, nd). Toxic substances, regardless of whether they are of animal, vegetable or mineral origin, were used throughout the history for political assassinations and sabotage; despite the risk of severe penalties, the prospects for success favoured the use of toxic substances. Such use has always been reduced, however, since only a small number of people had access to substances and possessed the ability of learn how to use them (Pascal, 1999).

CBRN weapons are rightly viewed with a special sense of horror, their effects can be devastating and indiscriminating, and they take the most stringent toll among the most vulnerable population, non-combatants (e.g. a biological attack cannot be detected sufficiently fast after the disease spreads through the population). Moreover, chemical and biological weapons are a particularly attractive alternative for groups that do not have the ability to produce nuclear weapons, and this risk raises complex but important ethical issues (London, 2003). The common name for CBRN terrorism which causes the death of a large number of people, large scale damage and a strong echo worldwide is post-industrial or hyper-terrorism. This means that non-state elements possess and dispose of assets that were previously held only by states, but unlike them, which often fear reprisals after WMD attacks, terrorists, having no geographical location, are ready to use WMD with much less scrupulousness and fear (Kurmnik, Ribnikar, 2003). Some authors have described the factors that make chemical, biological, radiological and nuclear terrorist attacks in many ways unique and demanding, such as an element of surprise, invisible agents, ordnance, the risk of repetition and new types of risks (Ruggiero, Voss, 2015).

In the past 30 years, the use of CBRN weapons has become a major concern for many nations around the world. The public has become insensitive to traditional terrorist attacks that seem to be a less efficient way for 
terrorist organizations to achieve their goals. What causes shock and fear is actually presenting the properties of weapons which can be used by terrorist organizations to enhance their efforts and the effectiveness of attacks. CBRN terrorism is often a synonym for weapons of mass destruction, although this form of terrorism and related incidents do not require attacks and inflicting harm to large numbers of people - they do not even require deadly attacks at all. The number of studies on this type of terrorism is limited due to the lack of available data on this terrorism type. There is a very small number of databases of CBRN incidents, and even the existing ones have relatively little to do with them and they are compared to conventional terrorism (Jesse, 2012).

Some experts emphasize the factors that promote such attacks and these factors include the availability of information and expertise, increased frustration of terrorists, demonization of the target population, as well as a millennial, apocalyptic or messianic vision. Experts also differ in opinion when it comes to possible perpetrators of CBRN incidents, and include religious fundamentalists and cults ${ }^{1}$ as possible perpetrators of such attacks, especially when these groups address to ethereal audience, emphasizing the hatred of unbelievers (Ivanova, Sandler, 2007).

Concerns about super terrorism which involves the use of CBRN weapons are mainly focused on what terrorists can do in the context of our social reality, with an emphasis on terrorist motivations, initiatives and limitations. When considering which terrorist groups may be inclined to commit CBRN terrorism, it is important to recognize the spectrum of these acts, as well as to analyze the following categorization: (a) massive casualty events produced by conventional weapons; (b) CBRN scams; (c) conventional attack on a nuclear facility; (d) limited-scale chemical or biological attack or a radiological dispersion; (e) large scale chemical or biological attack or a radiological dispersion; and (f) CBRN strikes (super terrorism) that can lead to thousands of victims. In addition to the motivation and willingness to inflict mass casualties in any way, terrorists must have technical and financial capabilities to come into possession of material and acquire skills for these types of weapons and materials and carry out a successful attack. Chemical and biological weapons can pose a risk to terrorists thus deterring them from using such weapons (Post, 2005, pp.148-151).

\footnotetext{
${ }^{1}$ The question of whether there is a new trend towards massive casualty attacks remains at least partially opened as well as the link between religious terrorism and willingness to kill indiscriminately and even use weapons of mass destruction,, which is so evident in discussions of new terrorism. Therefore, it should be noted that the historical evidence does not support the idea that there are greater chances that religious groups use chemical or biological agents (Tucker, 2001, pp.1-14).
} 
The possibility that terrorists use chemical or biological substances may increase over the next decade, according to US intelligence agencies. According to $\mathrm{ClA}^{2}$, an interest among non-state actors, including terrorists, for biological and chemical materials is real and growing, and the number of potential perpetrators is increasing. The agency also noted that many of these groups had developed an international network and did not need to rely on state sponsors for financial and technical support. However, it is believed that it is less likely that terrorists would choose chemical and biological weapons over conventional explosives, because these weapons are difficult to control and their results are unpredictable (Condesman, Burke, 2001).

The risk of CBRN weapons is growing since terrorists are better acquainted with these agents and their potential for causing harm ${ }^{3}$. These agents possess desirable characteristics as weapons of terror; they are biologically invisible to the naked eye, odorless and potentially lethal in the form of particles; natural organisms are so readily available, and can be "camouflaged" in natural disasters and used to spread fear and various diseases. Chemical agents quickly attack the critical physiological centers of the body, disabling or killing the victim. Biological and chemical weapons require the application of huge amounts of resources and result in different effects, causing fear and panic in the contaminated areas. Often referred to as "weapons of mass destruction", but, in medical terms, they are weapons of potential mass casualties because they can lead to massive death toll in the absence of preventive measures and timely response (Meyer, Spinella, 2014, pp.645-656). "Bioterrorism is the intentional use of microorganisms or toxins derived from living organisms used for hostile purposes intended to cause disease or death in man, animals and plants, on which they depend". The threat of bioterrorist attacks is real, and each individual is a potential terrorist, when terrorists are "invisible" prior to an attack which also can be "invisible" in the form of causing infectious disea-

\footnotetext{
2 In 1999, a biparty commission led by former CIA director John Deutch released its report on the readiness of the US to deal with weapons of mass destruction. While the commission expressed concerns about the armament of Russians with nuclear explosives and about Chinese exports of missile materials, it was also upset by terrorist storage of biological weapons. The worst nightmare of the Commission was a possibility of anthrax attacks which can send a huge number of people into hospitals. Just because terrorists have not shown much interest and success with biological weapons in the past, does not mean they will not use them in the future. Reports indicate, with different levels of reliability, that Osama Bin Laden, Islamist Jihad and the Kurdish PKK have shown interest in biological weapons in recent years. "These events did not escalate, but they certainly could have" (Carus, 1999)

${ }^{3}$ For example, ten kilograms of anthrax are as deadly as nuclear explosive of 10 kilograms, but they are cheaper and easier to buy and carry (Gompert, 2000 pp.22-23.).
} 
ses or epidemics. Citizens who are not aware they are infected are potential safety hazard and so-called dangerous bodies (Mijalković, 2011).

In the last ten years, the issue of CBRN weapons has attracted the attention of experts, but a list of priorities by the heads of states has never been established. Biological weapons almost became forgotten after they had been banned by the 1972 Convention on Biological Weapons. A significant attention was paid to them during the 90 s of the last century. The important thing is that biological weapons attract much less attention than other similar weapons, but probably represent the greatest danger, and in addition to their use in war, they are available as instruments of terror in peace. Some countries showed willingness to use such weapons against defenseless populations to achieve strategic objectives, and in this regard, some analysts believe that those who attacked the World Trade Center in 1993 applied cyanide on their bombs (this was not confirmed, but a large amount of cyanide was found in possession of the perpetrators). Such a group will prove to be less inefficient, because if terrorists decide to shock and surprise the government by inflicting enormous damage, CBRN weapons will become more attractive and more accessible (Bettis, 1998).

Motives and forms of behavior of individuals and groups who acquired or used CBRN weapons have existed since long ago and there is no doubt that modern society is vulnerable to such attacks (Tucker, 2000). Fear of biological terrorism is certainly greater than the fear of the conventional forms of terrorism; some of these fears are justified and some are often exaggerated. Some agents are really very contagious and deadly, and if used properly, have a potential to result in casualties similar to those in a nuclear attack. Perhaps the scariest aspect of biological weapons is that the body is attacked without warning, people are afraid of the threat as it is invisible, and cannot be heard or felt. The history of warfare, terrorism and crime involving biological agents in the last century is considerably less dangerous and more deadly than the history of conventional warfare (Parachini, 2001). Today, some states and some terrorist groups can more easily overcome technological barriers due to the increased flow of information and access to previously unavailable technologies. Along with nuclear and chemical weapons, biological weapons are part of an unholy trinity of weapons of mass destruction (Davis, Johnson-Winegar, 2000, pp.15-28).

The society is now faced with the threat of an apocalyptic and asymmetric war scenario in which kamikaze attackers are able to arm 
themselves with $\mathrm{WMD}^{4}$ without even having to have a "physical" weapon to create fear; they probably still prefer simple, proven methods: a stampede in an enclosed place, or just an explosive device, which will kill many people ${ }^{5}$ (Palmer, 2004, pp.3-9). Early detection and response to biological or chemical terrorism are crucial to solving this problem (U.S. Congress House, 2003, p.117).

\section{Potential devastating effects of CBRN terrorist attacks}

Unlike nuclear terrorism, which remains problematic and complex to implement and is still largely theoretical, chemical terrorism is concrete and practical, and in several cases has already been used. In biological terrorism, attacks are not direct and immediate, they become apparent only after a few hours or days (after some victims leave the scene of the attack) when it may be more difficult to detect the perpetrator and the motive of the attack (Ganor, 1998). The act of biological or chemical terrorism can range from aerosol anthrax ${ }^{6}$ to contamination of food products. It is important to predict when and how such an attack may or may not occur. Preparing the nation to confront this threat poses a major challenge, but it should be noted that the unpreparedness can have devastating effects (U.S. Department of Health and Human Services, 2000). Biological terrorism offers a possibility of a reattack, which adversely affects the confidence and constantly asks for investing resources to achieve a specific model of defense. If an attack is repeated, and the state is not sufficiently prepared, then the corrosive psychological and political consequences of the attack will be even bigger, because people will want to know why more has not be done on this issue (Danzing, 2003).

\footnotetext{
${ }^{4}$ From 1975 to the mid-2000s, there were only 126 chemical and biological attacks around the world.

${ }^{5}$ Unlike the attacks on New York and Washington, a biological attack would not be accompanied by explosions and police sirens; instead, terrorists could unleash a deadly biological weapon in a crowded mall or a metro station, which poses a danger to millions of people (US Congress Senate 2001, p.255)

${ }^{6}$ The World Health Organization estimates that, 3 days after releasing $50 \mathrm{~kg}$ pores of bacteria within $2 \mathrm{~km}$ in a city of 500,000 inhabitants, favorable winds could lead to infection of even 125,000 people, producing 95,000 deaths and this number is much more deadly than in any other scenario of the release of this agent (Cieslak, Eitzen, 1999, pp.552-555). An anthrax bacterium that causes deadly disease is common in cattle and sheep but the real danger is actually its potential to be used in a terrorist attack, because it is odorless and tasteless, invisible and not immediately visible in the attack; only a few hours later, people who ingest the bacteria start to experience symptoms of choking. Later, medical help would be of no use (Foer, 1998).
} 
There is a common misperception that carrying out a biological terrorist attack is easy; in fact, any wrong step in the preparatory phase (a strain must be cultivated under aerobic or anaerobic conditions, it should be purified in order to give the best results) can make an attack ${ }^{7}$ fail. There are also possibilities for a series of missteps during the spreading, due to ignorance and improper dosage; it is necessary to obtain the desired effect, to analyze the ventilation system in a building - or wind speed and direction if an open attack is planned - and misconceptions regarding the path of agents entering the body (Lowe, Carus, 2016).

Chemical and biological weapons vary in effects and ease or difficulty in production and applications; from a philosophical perspective, these weapons have been with us for millennia. However, the industrial age resulted in a mass production and expansion of these weapons, together with the development of a number of stronger agents as compared to those that already occur in nature (Kopp, 2008). The use of chemicals as weapons of mass destruction poses a real threat, as well as a clear and present danger to Western societies. The 1995 gas attack in Tokyo proves that these chemicals can be delivered in a way that requires little sophistication, which makes it very attractive to terrorists (Rivera, 2013). ${ }^{8}$ On the surface, it seems that both Reineesh and Aum Shinrikio ${ }^{9}$ cults resorted to chemical and biological terrorism to prevent attempts of law enforcement to interfere in their activities; however, the deeper motivations and intentions were fundamentally different, which contributed to significant deviations in their preparations for CBRN terrorism and the agent selection. Such differences are significant in the assessment and review of risks and consequences (Zenders, et. al, 2006).

Chemical, biological and toxicological weapons can produce mass casualties if they are effectively spread, but they produce different effects. Chemical weapons, mainly composed of synthetic chemicals, need the largest amounts of material to be effective and cause the effects lasting from a couple of minutes to several hours. These weapons are actually

\footnotetext{
${ }^{7}$ One reason why there were so few successful attacks of chemical or biological terrorism is because a successful attack requires overcoming a series of major technical obstacles: accessing specialized chemical substances or infectious types of microbes, procurement of equipment and knowhow for the production of agents and their dissemination; developing an organizational structure that is able to resist infiltration or early detection of law enforcement.

8 This cult initiated at least nine biological attacks in the early 1990s, using anthrax spores or germs that cause botulism, but all these attempts failed. In addition, laboratory cultures of viruses and bacteria are often kept in ideal conditions, but may not be so strong in the real world (Hall, 1998, p.92).

9 The above-mentioned attack on the subway in Tokyo was designed to prevent a police raid on their premises. A year earlier, the same group carried out a less-known sarin attack in Matsumoto, which led to 7 deaths and 600 wounded; the attack was directed against the judges representing the government in a dispute with the cult over land.
} 
chemical compounds that are harmful to the human body, even when entered in small doses, and the effects may occur very soon after exposure, from several minutes to several hours. Biological weapons are made of natural pathogens that require a minimum of material to be effective, but generally have an incubation period of several days before they cause symptoms. As a result, these weapons require much less material than usual chemicals and they need more time to produce effects; diseases caused are primarily debilitating, such as $\mathrm{K}$ fever or smallpox which may be fatal. Infectious pathogens such as smallpox ${ }^{10}$ have the potential to extend the effects of the attack among victims, and the symptoms will require a lot of time to develop, so a covert biological attack may be recognized only after several days (Shea, 2004).

Chemical weapons (first used in World War I) can include any of a number of different substances, each of which has its own application, but they all can cause enormous suffering and death. Chemical weapons were first used in World War II. The agent known as "gas" (actually a vapor or aerosol of toxic substances) consisted of commercial chemicals used to kill pests. In addition, the aforementioned chemicals have terrible consequences, causing long-lasting pain and usually agonizing death, which is why they are often used by terrorists and fanatics (Baker, 2006). Also, the modalities used to commit terrorist attacks in Oklahoma City, Japan, Madrid and New York, range from conventional high explosives to chemical and biological weapons, all of which were used in the recent past. High-order explosive (HE) was the first available explosive after Alfred Nobel invented dynamite in 1866, and, since then, several others have been developed and used in up to $66 \%$ of terrorist attacks (Hamele, Bradley Poss, Sweney, 2014, pp.15-23).

One should be aware of potential bioterrorist acts - their probability is completely unknown, and an attack might even never happen. However, we have seen that terrorism can occur as one of the most painful problems of the post-cold war period and that the terrorists are always on a lookout for new weapons (Shallala, 1999, pp.492-494). Hazardous biological agents can be distributed through air, food, water, or insects, their effects can be seen after a few days, during which the infectious disease can spread to others who were not initially exposed. Some biological agents such as anthrax and plague produce symptoms that are easily confused with the flu or other less infectious diseases, leading to delays in diagnosis and identification (Report to Congressional, 2003, pp.117).

10 This virus, which is among the most dangerous organisms that could be used for bioterrorism, is not widely available and the international trade on the black market in weapons of mass destruction is the only way to gain access to its possession (O'Toole, 1999, pp.540-546). 


\section{Nuclear and radiological materials as weapons of mass destruction}

The possibility that terrorists use weapons of mass destruction has become undeniable and probably because of that interest for terrorism appeared also in the natural sciences. Scientific American, a general scientific journal, published an article entitled "Thwarting nuclear terrorism", whose subtitle states that "many reactors studied have a high degree of enriched uranium that terrorists could use to build nuclear bombs." This can be seen as a means of proving the growing willingness to treat terrorism as an expansive pandemic that threatens the very existence of human civilization (Wolf, Frankel, 2007, pp.259-279). Nuclear material is more difficult to obtain than biological or chemical precursors, but it is more and more accessible due to the deterioration of the situation in the countries of the former USSR (Elland, 1998, pp.26-40).

The nuclear terrorist attack is an event in which a terrorist organization uses a nuclear bomb to cause mass murder and destruction. This form of terrorism also includes the use or threat of use of weapons based on the fission of radioactive materials as well as attacks on nuclear power plants in order to produce enormous and irreparable damage to the environment. In the latter case, a terrorist organization does not need to develop, possess or take control of a nuclear bomb that would cause great harm. It just needs to use a conventional weapon against one of many nuclear reactors in the world, seriously damaging it and releasing radioactive substances into the atmosphere in such a way to endanger a large number of people. Terrorists can buy or come into possession of nuclear weapons from any country, especially from a country that supports terrorism, because many "revolutionary" states of the "Third World", such as Iran, Iraq and Libya ${ }^{11}$ actively and regularly assist various terrorist organizations (Ganor, 1998).

The question is why terrorists would, despite all the accompanying difficulties and obstacles, decide to use weapons of mass destruction? Attracting attention is certainly one of the primary reasons because released toxic particles, including radioactive ones, cause much greater amount of fear than their real destructive power. This fact is especially attractive to those terrorist groups who feel that no one takes them seriously any more,

\footnotetext{
${ }^{11}$ Consent to bomb El Shifa was given by fewer than ten highest officials of the United States, who supported the charges that this city produced chemicals for weapons and not just stored or reloaded them. However, Clinton's advisers claimed they had no new evidence to support the conclusion that the mentioned factory was linked to Bin Laden and the development of Iraq's chemical weapons program (Whitelaw, et al, 1999).
} 
because the government or the public eventually become insensitive to their stories and requirements (Stern, 2004).

The possibility of devastating attacks, including possibly weapons of mass destruction is very real and we should not neglect the fact that $\mathrm{Al}$ Qaeda has aggressively sought nuclear materials from its earliest days and biological weapons since the late 1990s, which could have farreaching consequences and implications for the security of individual states, where the basic living conditions would be violated and the trust in the American political system undermined (Benjamin, 2008).

Nuclear detonation by terrorists would probably lead to massive casualties. In contrast, a radiological attack is likely to be less violent, but could significantly contaminate the urban environment, causing economic and social collapse and both types of attacks could have significant psychological impact on the human population. Thorough analyses from previous years have concluded that it is a difficult task for terrorists to construct weapons of mass destruction, but regardless of this, terrorist organizations may over time develop such a possibility, if they get enough fissile material, perhaps through theft (O'Neill, 1997). Two options for the construction of nuclear devices by terrorists are: to use the earliest design principles, the so-called rough design that uses more advanced principles in the framework of the so-called sophisticated design. A rough design is discussed primarily in the context of the problems faced by terrorist groups. Schematic fission explosive materials from the oldest to the most modern types show, in a qualitative way, the principles that are used to achieve the first fission explosions are widely available; however, detailed drawings and specifications that are essential before it is possible to plan the development of specific parts are not available (Mark, et al, 1987).

Terrorists are trying in every way to come into possession of weapons of mass destruction, which is one of the most serious threats to the human race and the means of attack may include a range of systems, from highly sophisticated weapons such as atomic bombs to underdeveloped improvised radiological devices. Although high explosives are not traditionally recognized as WMD weapons, high yields of some low-yield explosives caused significant devastating consequences for both people and their surroundings (Terrorism and WMD, 2007). The concept of nuclear terrorism is probably the least understood of all other hazards arising from nuclear weapons, simply because it is known that terrorist groups are developing and coming into possession of nuclear weapons. Therefore, the seriousness of these threats remains questionable; conventional notions indicate that nuclear terrorism is too hard to undertake because it would require considerable effort, expertise and competence of perpetrators (Schwartz, 2013). 


\section{Conclusion}

The international community is trying to identify a set of early warning signs and the most important indicators of possible future activities of terrorists who acquire and use unconventional CBRN weapons as a means of achieving their goals. Many believe that it is only a matter of time when another CBRN terrorist attack will occur, where the form, time and place of the attack are unpredictable. There is a relatively small set of data in the formulation of general observations about the terrorists' potential of using unconventional weapons; in addition, details on many of these cases are incomplete and often ambiguous, which only further complicates the task of accurately and credibly describing the scope and size of the risk. The use of CBRN weapons can transform the way countries wage wars, and if used on a large scale against civilians, it could redraw the patterns of society because people are becoming more concerned about the casualties of this silent and deadly type of war. We see that terrorists continually search for new weapons, and scientists predict that in the next few decades, these weapons will pose an enormous challenge. As with the emergence of infectious diseases, early detection and control of biological or chemical attack depend on a strong and flexible public health system at the local, state and federal level. The first challenge for the population is to be aware that the act of bioterrorism might happen and its probability is completely unknown and uncertain; the attack may never happen, but the fear is certainly present. However, it has been proved that terrorism can occur as one of the most painful problems of the post-cold war era. In the event of a biological or chemical attack, there is no effective radar or a device that can it identify in time - it is this unpredictability that equally concerns government officials and ordinary citizens alike. CBRN weapons are weapons of terror and therefore their attractiveness, efficiency and psychological effects have reflected on individuals, groups and social levels. Health infrastructures and the public must be prepared to prevent diseases and injuries that could occur due to biological and chemical terrorism, especially during covert terrorist attacks.

\section{References}

Baker, D., 2006. Fighting Terrorism: Biological, Nuclear, and Chemical Weapons. SIRS Discoverer.

Benjamin, D., 2008. Strategic Counterterrorism. Foreign policy at brookings. Police paper no. 7 . 

$77(1)$.

Bettis, R., 1998. The New Threat of Mass Destruction. Foreign Affairs,

Bioterrorism, chemical weapons, and radiation terrorism, nd. Available at: http://nursece4less.com/tests/materials/n029cmaterials.pdf.

Mark, J.C., Taylor, T., Eyster, E., Maraman, W., Wechsler, J., 1987. Can terrorists build nuclear weapons? Lexington Books, United States.

Carus, S., 1999. Biohazard. The New Republic.

Cieslak, T.J. \& Eitzen, E.M., 1999. Clinical and epidemiologic principles of anthrax. Emerging Infectious Diseases, 5(4), pp.552-555. U.S. Department of Health and Human Services, Atlanta, Georgia: National Center for Infectious Diseases, Centers for Disease Control and Prevention.

Condesman, A., \& Burke, A., 2001. Chair in Strategy Asymmetric and terrorist attacks with chemical weapons. CSIS Homeland Defense: Asymmetric Warfare \& Terrorism.

Danzing, R., 2003. U. S. Catastrophic bioterrorism: What is to be done? Washington, DC: National Defense University - Center for Technology and National Security Policy - Department of Defense. August; U. S. Government Printing Office.

Davis, J., \& Johnson-Winegar, A., 2000. The Anthrax Terror DOD's Number-One Biological Threat. Aerospace power journal, pp.15-28, winter.

Eland, I., 1998. Defending Other Nations: The Risk to America's Homeland. USA Today magazine, 127(2640).

Foer, F., 1998. Toxic Shock. The New Republic.

Ganor, B., 1998. Non-Conventional Terrorism: Chemical, Nuclear, and Biological. ICT Institute for Counter-Terrorism (ICT).

Gompert, D.C., 2000. Sharpen the Fear. The Bulletin of Atomic Scientists, 56(1), pp.22-23.

Hall, S., 1998. Science-Fiction Policy. Technology Review (Cambridge, Mass.), 101(6), p.92.

Hamele, M., Bradley Poss, W., Sweney, J., 2014. Disaster preparedness, pediatric considerations in primary blast injury, chemical, and biological terrorism. World J Crit Care Med, 3(1), pp.15-23. Available at: http://dx.doi.org/10.5492/wjccm.v3.i1.15.

Ivanova, K., \& Sandler, T., 2007. CBRN Attack Perpetrators: An Empirical Study. Published Articles \& Papers. Paper 65.

Jesse, C., 2012. Optimization of nuclear, radiological, biological, and chemical terrorism incidence models through the use of simulated annealing Monte Carlo and iterative methods. [Internet]. Available at:

https://smartech.gatech.edu/bitstream/handle/1853/43599/coyle_jesse_a_20120 5 mast.pdf. Accessed: 24 May 2016.

Kopp, C., 2008. Chemical and biological weapons. Center for Strategic and International Studies. 
Kurmnik, B., \& Ribnikar, D., 2003. Asymmetric wars. Belgrade: Evro Giunti. London, A.J., 2003. Threats to the Common Good: Biochemical Weapons and Human Subjects Research. Department of Philosophy. Paper 404.

Lowe, K., \& Carus, S., 1997. Chemical and Biological Terrorism: Threat and Response. Washington Institute. Policy 2016, printed with permission PolicyWatch 247.

Meyer, M., Spinella, P., \& Cieslak, T., 2014. Pediatric Critical Care Medicine. Chapter: Agents of Biological and Chemical Terrorism, pp.645-656. [e-book]. Available at: https://link.springer.com/chapter/10.1007\%2F978-1-4471-63626_46. Accessed: 22 May 2016.

Mijalković, S., 2009. Nacionalna bezbednost. Zemun: Kriminalističkopolicijska akademija.

O'Toole, T., 1999. Smallpox: An attack scenario. Emerging Infectious Diseases, 5(4), pp.540-546. U.S. Department of Health and Human Services, Atlanta, Georgia: National Center for Infectious Diseases, Centers for Disease Control and Prevention.

O'Neill, K., 1997. The Nuclear Terrorist Threat. Institute for Science and International Security.

Palmer, I., 2004. The psychological dimension of chemical, biological, radiological and nuclear (CBRN) terrorism. J R Army Med Corps, 150(1), pp.3-9.

Parachini, J., 2001. Combating Terrorism: Assessing the Threat of Biological Terrorism. [Internet]. Available at:

https://www.rand.org/content/dam/rand/pubs/testimonies/2005/CT183.pdf. Accessed: 22 May 2016.

Post, J.M., 2005. The Psychology of WMD Terrorism. International Studies Review, 7(1), pp.148-151. Available at: https://doi.org/10.1111/j.1521-9488.2005.479_6.x.

Ruggiero, A., \& Vos, M., 2015. Communication Challenges in CBRN Terrorism Crisis: Expert Perceptions. Journal of Contingencies and Crisis Management, 23(3) pp.138-148. Available at: https://doi.org/10.1111/1468-5973.12065.

Schwartz, R., 2013. Case Study - Syria's Chemical and Biological Weapons Program and the Use of These Weapons in the Syrian Civil War Today. [Internet]. Available at: https://www.ict.org.il/Article/694/Case\%20Study-SyriasChemical-and-Biological-Weapons-Program. Accessed: 20 May 2016.

Shea, D.A., 2004. Terrorism: Background on Chemical, Biological, and Toxin Weapons and Options for Lessening. CRS Report for Congress. [Internet]. Available at: http://www.investigativeproject.org/documents/testimony/65.pdf. Accessed: 21 May 2016.

Stern, Dz., 2004. Extreme terrorists. Belgrade: Alexandria pres.

Tucker, J., 2000. Toxic Terror: Assessing Terrorist Use of Chemical and Biological Weapons. The MIT Press. Book.

Tucker, D., 2001. What Is New About the New Terrorism and How Dangerous Is It. Terrorism and Political Violence, 13(Autumn,) pp.1-14. 
U.S. Congress House, 2003. Committee on Energy and Commerce. Furthering public health security: project bioshield Subcommittee on Health; Subcommittee on Emergency Preparedness and Response. 108 Congress, 1 Session. 27 March. Washington, p.117.

U.S. Congress Senate, 2001. Committee on Appropriations. Subcommittee on Department of Labor, Health and Human Services, and Education, and Related Agencies. 107 Congress, 1 Session Bioterrorism, October-November, Washington, DC: U.S. Government, p.255.

U.S. Department of Health and Human Services, 2000. Biological and chemical terrorism: Strategic plan for preparedness and response. Morbidity and Mortality Weekly Report. 21 April Atlanta, Georgia: Centers for Disease Control and Prevention; Washington, DC: U.S. Government Printing Office.

Whitelaw, K., Strobel, P., \& Duffy, B., 1999. It Was a Direct Hit, but Was It the Right Target? U.S. News \& World Report, 127(7).

Wolf, Y., \& Frankel, O., 2007. Terrorism: Toward an overarched account and prevention with a special Reference to pendulum interplay between both parties. Aggression and Violent Behavior, 12(3), pp.259-279.

Zanders, P.J., Karlsson, E., Melin, L., Naslund, E., \& Thani, L., 2006. Fighting Terrorism: Biological, Nuclear, and Chemical Weapons Appendix. In: Risk assessment of terrorism with chemical and biological weapons.

\section{ТЕНДЕНЦИЯ ПРИМЕНЕНИЯ РАДИАЦИОННОГО, ХИМИЧЕСКОГО И БИОЛОГИЧЕСКОГО ОРУЖИЯ В ТЕРРОРИСТИЧЕСКИХ ЦЕЛЯХ}

\section{Марко М. Крстич}

Министерство внутренних дел Республики Сербия, Управление полиции города Шабац, г. Шабац, Республика Сербия

ОБЛАСТЬ: РХБ оружие и защита

ВИД СТАТЬИ: обзорная статья

ЯЗЫК СТАТЬИ: английский

Резюме:

Радиационный, химический и биологический терроризм (РХБО) сегодня представляет огромную проблему, а масштабы его угрозы, ввиду использования такого рода оружия создали новую эпоху терроризма, которая опаснее всех предыдущих, ибо с таким терроризмом пока неизвестно как бороться. Пугает фракт того, что террористы могут найти доступ к оружию массового поражения. Учитывая такое положение автор настоящей статьи провел анализ вероятности терактов с применением РХБО. Современный терроризм использует инструменты инновационных технологий, которые могут 
быть доступны каждому человеку в любой момент и в любом месте. Поэтому необходимо понимать каким образом изменилась поведенческая динамика террористических групп в эпоху новых технологий. Перспективы применения РХБО в террористических целях подтверждена многими странами, как острейшая угроза безопасности общества, требующая быстрых и эфрфрективных решений и реакции.

В данной работе подчеркивается насколько важно понимать роль неконвенционального оружия в руках террористических группировок, а также насколько сложно идентифицировать фракторы, вызывающие эскалацию террористическх действий. Данный вопрос стал особенно актуален после трагедии 11 сентября 2001 года, хотя представители власти многих стран несколько лет до этого выражали беспокойство на счет того, что неконвенциональное оружие может быть использовано террористическими структурами и направлено против отдельных государств.

Ключевые слова: терроризм, РХБ оружие, неконвенциональное оружие, новые технологии, вызов безопасности.

ТЕНДЕНЦИЈА УПОТРЕБЕ ХЕМИЈСКОГ, БИОЛОШКОГ, РАДИОЛОШКОГ И НУКЛЕАРНОГ ОРУЖЈА У ТЕРОРИСТИЧКЕ СВРХЕ

Марко М. Крстић

Министарство унутрашњих послова Републике Србије, Полицијска управа у Шапцу, Шабац, Република Србија

ОБЛАСТ: НХБ оружје и заштита

ВРСТА ЧЛАНКА: прегледни чланак

ЈЕЗИК ЧЛАНКА: енглескИ

Сажетак:

Хемијски, биолошки, радиолошки и нуклеарни тероризам (CBRN) данас је озбиљан проблем, а његова претња и коришћење представља увод у нову епоху тероризма - епоху много опаснију од било ког претходног периода и тероризма са којим нико још не зна како да се носи. Узнемирујућа је чињеница да терористи могу да дођу у посед оружја за масовно уништење, а циљ рада је анализа вероватноће CBRN терористичких акција где је истакнута све већа забринутост и све већи знаци конвергенције између тероризма и неконвенционалних CBRN оружја у терористичке сврхе. Teроризам данас укључује технологије доступне свакоме, било где и када, распоређене кроз иновативна решења, где је неопходно такоЂе разумети комплексну интеракцију између динамике понашања терористичких група и одлука у вези са старим и новим техноло- 
гијама. Перспективу употребе CBRN тероризма потврдиле су многе државе као акутни безбедносни изазов који изискује ефикасан и брз одговор и реакцију. У раду ће, такође, бити расветљен однос између терористичких група и неконвенционалних оружја, као и тешкоће у идентификацији фрактора који могу изазвати његову ескалацију. Након трагедије 11. септембра 2001. године, али и неколико година пре, званичници многих држава истакли су могућност да терористичке организације временом дођу у посед неконвенционалних оружја и развију могућности њихове употребе против појединих држава.

Кључне речи: тероризам, хемијско оружје, биолошко оружје, радиолошко оружје, нуклеарно оружје, неконвенционална оружја, нове технологије, безбедносни изазов.

Paper received on / Дата получения работы / Датум пријема чланка: 22.06.2016.

Manuscript corrections submitted on / Дата получения исправленной версии работы / Датум достављања исправки рукописа: 18.12.2016.

Paper accepted for publishing on / Дата окончательного согласования работы / Датум коначног прихватања чланка за објављивање: 20.12.2016.

(c) 2017 The Author. Published by Vojnotehnički glasnik / Military Technical Courier (www.vtg.mod.gov.rs, втг.мо.упр.срб). This article is an open access article distributed under the terms and conditions of the Creative Commons Attribution license (http://creativecommons.org/licenses/by/3.0/rs/).

() 2017 Автор. Опубликовано в "Военно-технический вестник / Vojnotehnički glasnik / Military Technical Courier" (www.vtg.mod.gov.rs, втг.мо.упр.срб). Данная статья в открытом доступе и распространяется в соответствии с лицензией "Creative Commons" (http://creativecommons.org/licenses/by/3.0/rs/).

(C) 2017 Аутор. Објавио Војнотехнички гласник / Vojnotehnički glasnik / Military Technical Courier (www.vtg.mod.gov.rs, втг.мо.упр.срб). Ово је чланак отвореног приступа и дистрибуира се у складу са Creative Commons licencom (http://creativecommons.org/licenses/by/3.0/rs/).

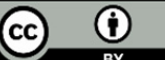

